\title{
Retargeting Strategies for Oncolytic Herpes Simplex Viruses
}

\author{
Gabriella Campadelli-Fiume, Biljana Petrovic, Valerio Leoni, Tatiana Gianni, Elisa Avitabile, \\ Costanza Casiraghi * and Valentina Gatta *
}

Department of Experimental, Diagnostic and Specialty Medicine, University of Bologna, Bologna 40126, Italy; gabriella.campadelli@unibo.it (G.C.-F.); bily.p@hotmail.it (B.P.); valerio.leoni2@unibo.it (V.L.);

tatiana.gianni3@unibo.it (T.G.); elisa.avitabile@unibo.it (E.A.)

* Correspondence: costanza.casiraghi@unibo.it (C.C.); valentina.gatta6@unibo.it (V.G.); Tel.: +39-051-209-4741

Academic Editors: E. Antonio Chiocca and Martine L.M. Lamfers

Received: 21 October 2015; Accepted: 30 December 2015; Published: 26 February 2016

\begin{abstract}
Most of the oncolytic herpes simplex viruses (HSVs) exhibit a high safety profile achieved through attenuation. They carry defects in virulence proteins that antagonize host cell response to the virus, including innate response, apoptosis, authophagy, and depend on tumor cell proliferation. They grow robustly in cancer cells, provided that these are deficient in host cell responses, which is often the case. To overcome the attenuation limits, a strategy is to render the virus highly cancer-specific, e.g., by retargeting their tropism to cancer-specific receptors, and detargeting from natural receptors. The target we selected is HER-2, overexpressed in breast, ovarian and other cancers. Entry of wt-HSV requires the essential glycoproteins $\mathrm{gD}, \mathrm{gH} / \mathrm{gL}$ and $\mathrm{gB}$. Here, we reviewed that oncolytic HSV retargeting was achieved through modifications in gD: the addition of a single-chain antibody (scFv) to HER-2 coupled with appropriate deletions to remove part of the natural receptors' binding sites. Recently, we showed that also $\mathrm{gH} / \mathrm{gL}$ can be a retargeting tool. The insertion of an $\mathrm{scFv}$ to HER-2 at the gH N-terminus, coupled with deletions in $\mathrm{gD}$, led to a recombinant capable to use HER-2 as the sole receptor. The retargeted oncolytic HSVs can be administered systemically by means of carrier cells-forcedly-infected mesenchymal stem cells. Altogether, the retargeted oncolytic HSVs are highly cancer-specific and their replication is not dependent on intrinsic defects of the tumor cells. They might be further modified to express immunomodulatory molecules.
\end{abstract}

Keywords: oncolytic HSV; retargeting; HER-2

\section{The Need for Non-Attenuated Cancer-Specific Oncolytic HSVs}

More than twenty years have passed since a herpes simplex virus (HSV) was assayed for the first time in the experimental therapy of human glioblastomas, with the aim of killing the tumor cells and reducing the tumor burden [1]. This initiated the oncolytic virotherapy era. Subsequent efforts were aimed at improving the safety profile, by reducing the intrinsic virulence of the virus. In essence, safety was obtained at the expense of virulence through single or multiple deletions [2]. Most frequently, the oncolytic HSVs are deleted in the neurovirulence gene $\gamma_{1} 34.5$, and gain cancer specificity from the fact that a number of cancer cells are defective in mounting the innate protein kinase R (PKR) response to the virus [3,4]. Additional deletions were included to further improve the safety profile [5]. Attenuated natural mutants, exemplified by HF10, were also selected [6]. These viruses have been and still are being tested in clinical trials [7-18], for a review [19-21]. Viruses were safely administered intratumorally at doses up to $3 \times 10^{9}$ plaque forming units (PFU) [12]. In general, they exhibit a high safety profile and exert antitumor activity against a variety of tumor types [21]. However, because of 
their attenuation, robust growth occurs only in tumors with defects in innate response, autophagy, apoptosis, etc., or with high tumor proliferation rate.

The need for less restricted oncolytic HSVs led to the design of the first immunotherapeutic oncolytic HSVs. Rabkin and coworkers [22] engineered a replication-competent attenuated HSV expressing interleukin 12 (IL-12), designed to induce local and systemic antitumor immunity and favor a Th1 response. Markert, Gillespie and Whitley engineered HSV recombinants deleted in the $\gamma_{1} 34.5$ gene and expressing IL-12, IL-4 or IL-10 [23,24]. A phase 1 trial to test the efficacy of the IL-12-encoding virus in glioblastoma patients is now ongoing (ClinicalTrials.gov identifier NCT02062827). Coffin and coworkers engineered the gene encoding granulocyte macrophage-colony stimulating factor (GM-CSF) in a $\Delta \gamma_{1} 34.5$ virus (OncoVEX ${ }^{G M-C S F}$ ), to enhance dendritic cell recruitment and boost the host immune response against the tumor [25]. In a phase III clinical trial, the patients with metastatic melanoma lesions who received repeated intratumoral inoculations of the virus, later renamed talimogene laherparepvec (T-VEC), showed a statistically significant increased durable response rate and an increased overall survival (slightly statistically not significant), when compared to the patients that received subcutaneous injections of GM-CSF alone [26]. The U.S. Food and Drug Administration approved this product for the treatment of melanoma lesions in the skin and lymph nodes [27], and the European Medicine Agency recommended it.

\section{Overview of Tropism Retargeting Based on Modification of gD}

An alternative strategy to more potent oncolytic HSVs, capable of replicating and killing cancer cells independently of intrinsic defects in the tumor and overcoming most of the limitations imposed by the tumor heterogeneity, is to render the virus highly cancer-specific by retargeting its tropism to cancer-specific receptors of choice and detargeting from natural receptors. Such viruses carry no deletion and preserve the full-blown lytic capacity of wt-HSV. In the HSV field, this idea was first introduced by Glorioso and co-workers at a time when the number and the specific roles of the HSV glycoproteins involved in virus entry was still unclear [28].

It is now known that HSV entry is a multistep process that involves an attachment glycoprotein $\mathrm{gC}$, plus four essential glycoproteins $\mathrm{gD}, \mathrm{gH} / \mathrm{gL}$ and $\mathrm{gB}$ (Figure $1 \mathrm{~A}$ ). $\mathrm{gD}$ is species-specific and is thought to be the major determinant of HSV tropism. $\mathrm{gH} / \mathrm{gL}$ and $\mathrm{gB}$ represent the conserved fusion apparatus across the Herpesviridae family. gB has structural features typical of viral fusion glycoproteins [29-34]. Entry initiates with gD binding to one of its receptors: nectin-1, HVEM and modified heparan sulphates [35-38]. This binding triggers conformational changes in $\mathrm{gD}$, including the dislodgement of the C-terminus ectodomain, exposing the profusion domain [39-43]. The speculative part of the model envisions that activation spreads through intermolecular signalling from the receptor-activated $\mathrm{gD}$ to $\mathrm{gH} / \mathrm{gL}$ and then to $\mathrm{gB}$, or through the recruitment of the glycoproteins to a macromolecular complex [44]. gH/gL undergo conformational changes with displacement of gL [44]. gB executes the fusion between virion and cell membranes. It is unclear whether $\mathrm{gH} / \mathrm{gL}$ are simply intermediates in the activation cascade or participate in the fusion event $[45,46]$.

A breakthrough in HSV retargeting strategies was the identification of $\mathrm{gD}$ as the virion glycoprotein to be modified [47,48]. Zhou and Roizman engineered IL-13 in gD N-terminus. IL-13 is the ligand of the IL-13 Receptor $2 \alpha$, expressed in glioblastoma. The resulting virus was effectively retargeted to the IL-13R $2 \alpha$ and detargeted from HVEM [48]. Retargeting to urokinase plasminogen activator receptor ( $\mathrm{uPAR}$ ) was also explored [49]. A split form of $\mathrm{gD}$ or a mutation in $\mathrm{S} 34$ in $\mathrm{gD}$ were introduced for the purpose of detargeting the viral tropism from nectin-1 [47,49,50]. However, the effect of the S34 substitution was not universal [50], and the split gD virus grew at relatively low titers. 


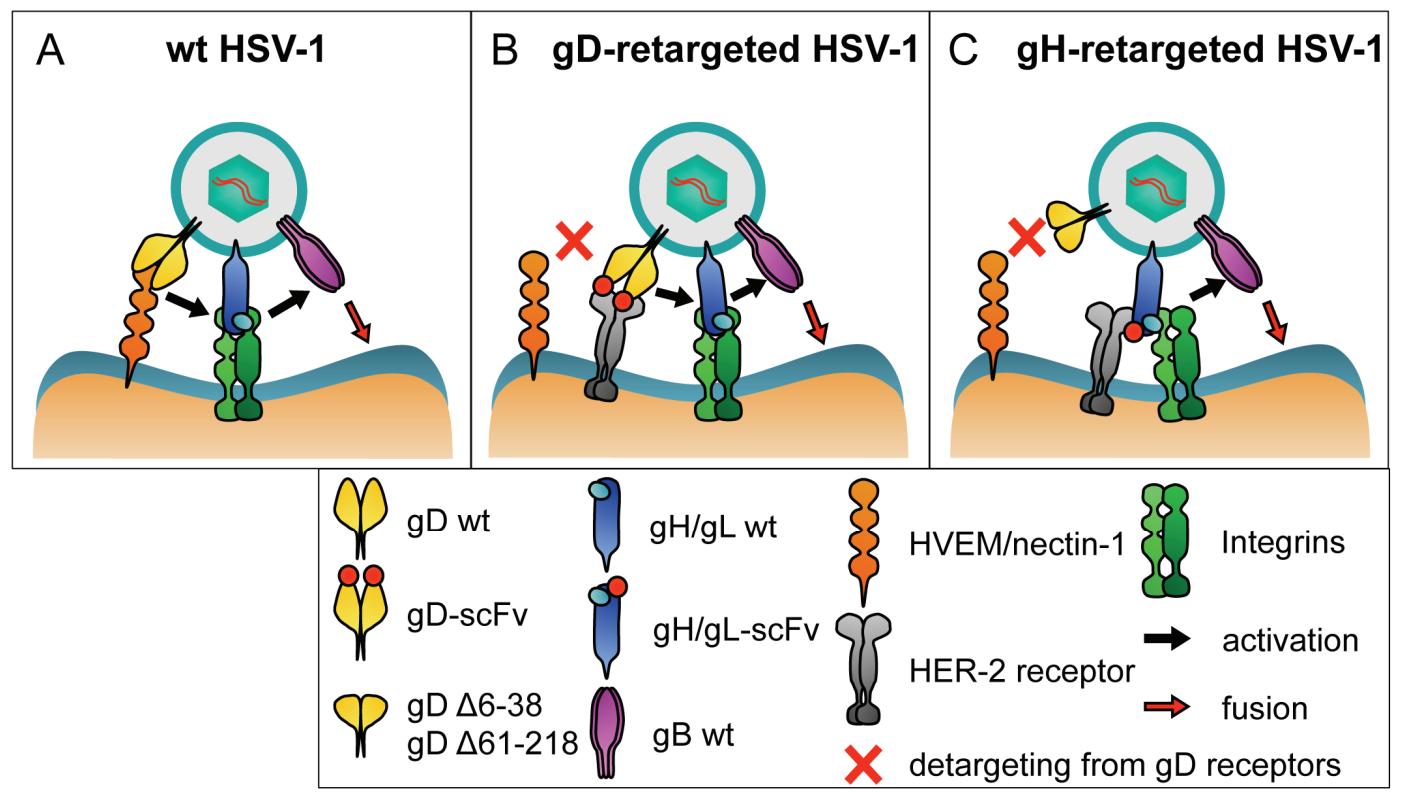

Figure 1. Schematic drawings showing the principle of tropism retargeting of oncolytic HSVs to cancer-specific receptors. (A) Essential interactions in entry of wt-HSV. gD is activated by the interaction with one of its natural receptors, nectin 1 or HVEM. The activation is transmitted to $\mathrm{gH} / \mathrm{gL}$, which are also activated by an integrin ( $\alpha \mathrm{v} \beta 6$ or $\alpha \mathrm{v} \beta 8$ ). The activation is finally signaled to $\mathrm{gB}$, the fusogenic glycoprotein that carries out the fusion of the virion envelope with the cell membrane, either the plasma or an endosomal membrane; (B) Retargeting through genetic modifications in $\mathrm{gD}$. gD carries the deletion of AA regions 6-38, or 61-218, which prevents the interaction of gD with its natural receptors. The deleted sequences are replaced with $\mathrm{scFv}$ to HER-2, for retargeting to HER-2. The interaction of the scFv-gD chimera with HER-2 activates gD. Activation is then transmitted to $\mathrm{gH} / \mathrm{gL}$ and to gB; (C) Retargeting through genetic modifications in $\mathrm{gH}$. gD carries the deletion of AA 6-38 to prevent the interaction with its natural receptors. $\mathrm{gH}$ carries an $\mathrm{scFv}$ to HER-2 inserted at its N-terminus. The interaction of the chimeric $\mathrm{gH}$ with HER-2 and with integrins is sufficient to activate $\mathrm{gH} / \mathrm{gL}$, in the absence of an activation signal from receptor-bound $\mathrm{gD}$. $\mathrm{gH} / \mathrm{gL}$ activation is signaled to $\mathrm{gB}$.

In our laboratory, we choose HER-2 (human epidermal growth factor receptor 2) as the target cancer-specific receptor. HER-2 is a member of the EGFR (epidermal growth factor receptor) family, overexpressed in breast and ovarian cancers, gastric carcinomas, glioblastomas, etc. [51]. Two fully retargeted oncolytic HSVs were generated (Figures 1 and 2). The gD regions that were deleted for detargeting purposes differ between these two oncolytic viruses (Figure 1). R-LM113 gD is deleted of the AA 6-38 N-terminal portion [50,52]. R-LM249 gD is deleted in the core region (AA 61-218) [53]. In both viruses, the single chain antibody $(\mathrm{scFv})$ to HER2 replaced the deleted portions of $\mathrm{gD}$ (Figure 2). The scFv to HER2 was derived from trastuzumab, a humanized MAb now in clinical practice, and interacts with HER-2 at a high affinity (29.3 nM) [54]. Overall, the in vitro growth of the two retargeted HSVs in cancer cells is about one log lower than that of the wt-virus $[50,53]$. A direct comparison with replication and killing ability of $\Delta \gamma_{1} 34.5$ viruses has not been performed yet. The safety profile of HER-2-retargeted oncolytic HSVs is predicted to be high. Thus, the deletions in $\mathrm{gD}$ rule out any possibility that the virus can revert to the wt-virus. In addition, in the unforeseen case that a same cell is double infected with a retargeted virus and a wt-virus, recombination events can only lead to the two parental viruses. 


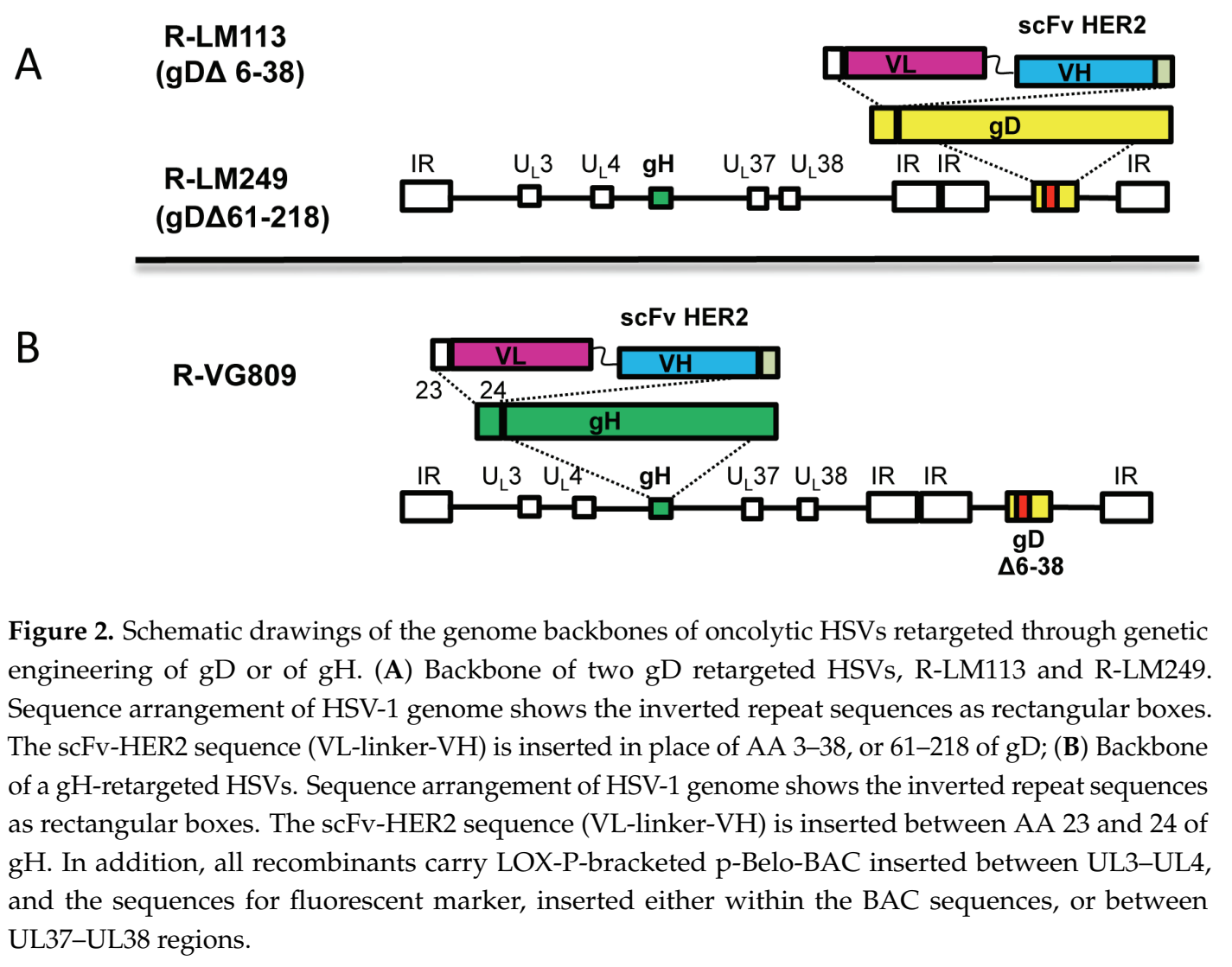

In preclinical experiments, we demonstrated a therapeutic effect of R-LM113 and R-LM249 against human breast and ovarian cancers, and against a murine model of HER2 ${ }^{+}$glioblastoma $[50,52,53,55,56]$. R-LM249 exerted a therapeutic effect against peritoneal and brain metastases of ovarian and breast cancers after intra-peritoneal injections [55]. R-LM249 can be administered systemically by means of carrier cells, and exerts therapeutic effects against lung and brain metastases [57]. The full retargeting observed in cell cultures holds true also in animals. We found evidence of viral replication exclusively in neoplastic deposits even in mice in which R-LM249 was administered through the i.p. route [55]. Even though the mouse system did not faithfully recapitulate the situation in humans (only the tumor cells expressed human HER-2), R-LM249 failed to infect off-target HER-2-negative cells.

Glorioso and Grandi chose EGFR as the target receptor expressed in a number of cancers, including glioblastoma. For detargeting purposes, gD carried the deletion of AA 2-24 (detargeting from HVEM) and one AA was mutated (Y38C, detargeting from nectin-1). The scFv to EGFR replaced the deleted portion of $\mathrm{gD}$ [58]. Interestingly, the gD modifications were combined with mutations (D285N e A549T) in $\mathrm{gB}$, which increase the rate of entry. The EGFR-retargeted virus exerts therapeutic effects in an orthotopic mouse model of primary human glioma [58]. Taking into account the Glorioso-Grandi and our own approaches, it would seem that a general detargeting-retargeting strategy is the deletion and replacement of the AA 6-38 region in $\mathrm{gD}$.

Parenthetically, as noted by Miest and Cattaneo [19], even though HSV entry is more complex than that of the measles virus (MV), the tropism of both viruses can be modified using similar strategies. The basic idea that emerged is that retargeting is readily achieved with enveloped viruses, likely because the structure of glycoproteins imposes less constraints than the rigid structure of the capsid proteins. The best results were obtained with the enveloped viruses that encode two distinct glycoproteins for attachment and for fusion, exemplified by MV and HSV [59]. A positive feature of retargeted oncolytic HSVs and oncolytic MVs is that they can be detargeted from the natural receptors $[60,61]$. 


\section{Tropism Retargeting Based on Modifications of $\mathrm{gH}$}

Recently, we challenged the idea that any retargeting strategy for HSV would entail modifications to $\mathrm{gD}$ and asked whether $\mathrm{gH}$ can also serve as a retargeting tool. We were prompted by our recent discovery that HSV gH/gL interacts with two interchangeable receptors, $\alpha \mathrm{v} \beta 6$ - and $\alpha \mathrm{v} \beta 8$-integrin. These receptors participate in the HSV entry process by promoting virus endocytosis, and the displacement of $\mathrm{gL}$ from the $\mathrm{gH} / \mathrm{gL}$ heterodimer; most likely, the latter is part of the process of $\mathrm{gH}$ activation. We reasoned that if $\mathrm{gH} / \mathrm{gL}$ serve as receptor-binding glycoproteins, then a hetelogous ligand engineered in $\mathrm{gH}$ might redirect the viral tropism. It was known that $\mathrm{gH}$ can tolerate an insert at the N-terminus. Specifically, Krupp and Mettenleiter isolated a viable gL-minus pseudorabies virus recombinant carrying a gD-gH fusion [62]. Cohen and Eisenberg generated a similar HSV recombinant carrying a $\mathrm{gD}-\mathrm{gH}$ chimera, in which the entire ectodomain of $\mathrm{gD}$ was fused at the $\mathrm{N}$-terminus (residue 22) of $\mathrm{gH}$ [63]. This chimera was capable of complementing a $\mathrm{gD}^{-/-} \mathrm{gH}^{+}$virus or a $\mathrm{gD}^{+} \mathrm{gH}^{-/-}$virus. These findings provided evidence that $\mathrm{gH}$ tolerates an insert at the $\mathrm{N}$-terminus, and that the $\mathrm{gD}$ in the chimera may enable $\mathrm{gH}$ activation. However, since $\mathrm{gH} / \mathrm{gL}$ carry a binding site for $\mathrm{gD}$, the activation from $\mathrm{gD}$ located in cis, rather than in trans, was not totally surprising. However, it did not predict whether the $\mathrm{gH} / \mathrm{gL}$ activation could be achieved through a heterologous ligand, and whether this would result in modification to the HSV tropism.

We engineered the scFv to HER-2 at the N-terminus of gH, between AA 23 and 24 (Figure 2). AA 1-20 constitute the signal sequence, absent from mature $\mathrm{gH}$. Two recombinants were generated. R-VG803 carries a wt-gD. R-VG809 carries the deletion of AA 6-38 region in gD for detargeting purposes [64]. The redirected tropism of R-VG803 and R-VG809 to HER2 was documented as the ability to infect the receptor-negative J cells transgenically expressing a single receptor, i.e., HER-2, HVEM, or nectin-1, and as the ability to infect human or animal cell lines expressing HER-2. Both R-VG803 and R-VG809 infected J-HER2 cells, and the infection was blocked by trastuzumab-the MAb to HER-2 from which the scFv was derived. Thus, they use HER2 as the sole receptor, i.e., as the portal of entry, in the absence of a gD receptor (Figure 1C). In contrast to R-VG803, R-VG809 failed to infect J-nectin-1, or J-HVEM cells, as well as a panel of HER-2-negative human and animal cells, as expected. This property is consistent with the detargeting effect of the partial deletion in gD. In conclusion, we have defined the site of insertion of scFv to HER2 in gH and ascertained that it can be coupled with $\mathrm{gD}$ deletions for detargeting from natural receptors [64]. These findings support two key conclusions: (i) it is possible to modify HSV tropism through the insertion of a heterologous ligand in $\mathrm{gH}$; and (ii) a gH-retargeted-HSV is infectious even in the absence of a $\mathrm{gD}$ receptor capable of activating $\mathrm{gD}$.

\section{Additional Retargeting Strategies}

To restrict oncolytic viral replication to tumor cells, transcriptional retargeting was investigated. This approach consists in placing a key viral gene under the control of a promoter that is active in cancer cells only. For example, placing the $\gamma_{1} 34.5$ gene under the control of Musashi1 promoter restricts its expression to malignant glioma cells [65]. A similar approach was pursued for retargeting to prostate tumors: the essential $\alpha 47$ gene was transcriptionally regulated to achieve efficient viral replication in prostate cells [66]. Additional examples include hepatocellular carcinoma specific promoters [67] and regulation of the essential $\alpha 4$ by hypoxia-inducible factor (HIF)-responsive promoter [68]. Finally, micro-RNA target sequences were employed to further decrease off-target infection. Thus, Glorioso and Grandi inserted in the $\alpha 4$ gene the target sequences of miR-124, expressed in neurons and absent from the glioblastoma cells, to protect healthy tissue against virus replication [69].

\section{Systemic Delivery of Retargeted Oncolytic HSVs by Means of Carrier Cells}

The ideal route of delivery for oncolytic viruses in humans carrying metastatic disease is the systemic one. Viruses belonging to different species exhibit intrinsic differences in their ability to 
spread through the systemic route. Furthermore, given that the majority of systemically administered oncolytic viruses are rapidly cleared by parenchymal organs and inactivated by non-specific and specific defense systems, it may be very difficult, and most likely unsafe, to reach the high blood concentrations required to achieve the locally active concentrations. Further yet, there would be production problems [70]. In the case of oncolytic HSVs, the efficacy of the intravenous (i.v.) systemic route of administration has been attempted in a limited number of preclinical studies [71-74]. In a phase I clinical trial, the delivery through hepatic artery was safe and showed some efficacy $[15,75,76]$.

A recent approach to circumvent delivery obstacles envisions the use of carrier cells, which package the viral cargo and deliver it to the tumor. Initial studies employed irradiated tumor cells, which have not been pursued because of safety concerns [77-80]. The mesenchymal stem cells appear as a promising carrier. They accumulate within the tumor stroma because of hypoxic conditions and of tumor-associated expression of inflammatory chemokines. A limit is that the cancer-specificity of the oncolytic viruses may prevent infection of these cells. In addition, the adoptively transferred mesenchymal stem cells might contribute to feed the tumor. So far, mesenchymal stem cells have been assayed as a carrier of oncolytic HSV only in a few studies for intraperitoneal delivery or for local delivery to brain tumors $[79,81-87]$.

The use of mesenchymal stem cells as carriers of retargeted oncolytic viruses has not been attempted, likely because these cells exhibit scarse-null expression of the targeted receptors. Recently, we reported that mesenchimal stromal cells (MSCs) from different sources can be forcedly infected with an HER2-retargeted oncolytic HSV, by exposing the virion-MSC mixtures to the fusogenic agent PEG 6000 [57]. Progeny viruses spread from MSCs to cancer cells in vitro and in vivo. We evaluated the organ distribution and therapeutic efficacy in two murine models of metastatic cancers, following a single i.v. injection of infected MSCs. The highest concentration of carrier-cells and of viral genomes was in the lungs, the organs where the viral and cellular genomes accumulated at higher amounts for anatomical reasons. Viral genomes persisted throughout the body for at least two days. The growth of ovarian cancer lung metastases in nude mice was strongly inhibited, and the majority of treated mice appeared metastasis-free. The treatment also significantly inhibited breast cancer metastases to the brain in the NOD scid gamma mice, and reduced by more than one-half the metastatic burden in the brain [57]. Clearly, the therapeutic effects reflected the advantages of the system, i.e., the viral cargo was multiplied within the cells, and was shielded from defensive systems. We did not detect any increase in tumor burden in mice treated with uninfected MSCs, ruling out major side effects of MSC administration in mice.

\section{Conclusions}

The combined oncolytic and immunotherapy approaches have made a remarkable impact on the virotherapy field. It is now possible to treat tumors locally, and, at the same time, induce therapeutic effects at distal sites, by breaking the host tolerance to the tumor. However, there remains a need for less attenuated, highly cancer-specific oncolytic viruses, capable of replicating and spreading despite intrinsic defects and heterogeneity in the cancer cell population [2]. In addition, only a fraction of patients respond to immune checkpoint blockade therapies.

Our approach to non attenuated oncolytic HSVs has been the design of viruses which gain safety from the retargeting of the viral tropism to cancer-specific receptors. Here, we reviewed that, in addition to $\mathrm{gD}, \mathrm{gH}$ also can serve as a tool for retargeting, and that retargeted oncolytic HSVs can be administered systemically by means of forcedly infected mesenchymal stem cells. Interestingly, the finding that infection with the gH-retargeted oncolytic HSV can take place in the absence of gD-mediated activation impacts the current model of HSV entry based on a cascade of glycoprotein activation. The data argue that the activation that propagates from receptor-bound $\mathrm{gD}$ can actually be substituted by the binding of the scFv to HER2 to its cognate receptor, HER-2. In addition, the retargeting studies open the possibility to engineer double retargeted oncolytic HSVs. Patients carrying tumors with low level HER-2 expression are non eligible for therapy with the anti-HER2 
antibodies. These tumors often express alternative receptors of the EGFR family, and patients could benefit from a double retargeted oncolytic HSV. Double-retargeted oncolytic HSVs would also prevent the selection of cancer cells negative for the targeted receptor, a phenomenon that occurs frequently in patients treated with targeted therapies, e.g., with human antibodies to the cancer receptors.

Acknowledgments: Work at the authors' laboratory was funded by the European Research Council (ERC) Advanced grant \# 340060-7th Framework Program, and by IG14535 grant from the Italian Association for Cancer Research (AIRC).

Conflicts of Interest: The authors declare no conflict of interest.

\section{References}

1. Martuza, R.L.; Malick, A.; Markert, J.M.; Ruffner, K.L.; Coen, D.M. Experimental therapy of human glioma by means of a genetically engineered virus mutant. Science 1991, 252, 854-856. [CrossRef] [PubMed]

2. Ilkow, C.S.; Swift, S.L.; Bell, J.C.; Diallo, J.S. From scourge to cure: Tumour-selective viral pathogenesis as a new strategy against cancer. PLoS Pathog. 2014, 10. [CrossRef] [PubMed]

3. Chou, J.; Kern, E.R.; Whitley, R.J.; Roizman, B. Mapping of herpes simplex virus-1 neurovirulence to gamma 134.5, a gene nonessential for growth in culture. Science 1990, 250, 1262-1266. [CrossRef] [PubMed]

4. McKie, E.A.; MacLean, A.R.; Lewis, A.D.; Cruickshank, G.; Rampling, R.; Barnett, S.C.; Kennedy, P.G.; Brown, S.M. Selective in vitro replication of herpes simplex virus type 1 (HSV-1) ICP34.5 null mutants in primary human CNS tumours-Evaluation of a potentially effective clinical therapy. Br. J. Cancer 1996, 74, 745-752. [CrossRef] [PubMed]

5. Mineta, T.; Rabkin, S.D.; Yazaki, T.; Hunter, W.D.; Martuza, R.L. Attenuated multi-mutated herpes simplex virus-1 for the treatment of malignant gliomas. Nat. Med. 1995, 1, 938-943. [CrossRef] [PubMed]

6. Takakuwa, H.; Goshima, F.; Nozawa, N.; Yoshikawa, T.; Kimata, H.; Nakao, A.; Nawa, A.; Kurata, T.; Sata, T.; Nishiyama, Y. Oncolytic viral therapy using a spontaneously generated herpes simplex virus type 1 variant for disseminated peritoneal tumor in immunocompetent mice. Arch. Virol. 2003, 148, 813-825. [CrossRef] [PubMed]

7. Hu, J.C.; Coffin, R.S.; Davis, C.J.; Graham, N.J.; Groves, N.; Guest, P.J.; Harrington, K.J.; James, N.D.; Love, C.A.; McNeish, I.; et al. A phase I study of OncoVEX $G M-C S F$, a second-generation oncolytic herpes simplex virus expressing granulocyte macrophage colony-stimulating factor. Clin. Cancer Res. 2006, 12, 6737-6747. [CrossRef] [PubMed]

8. Kaufman, H.L.; Kim, D.W.; DeRaffele, G.; Mitcham, J.; Coffin, R.S.; Kim-Schulze, S. Local and distant immunity induced by intralesional vaccination with an oncolytic herpes virus encoding GM-CSF in patients with stage IIIc and IV melanoma. Ann. Surg. Oncol. 2010, 17, 718-730. [CrossRef] [PubMed]

9. Senzer, N.N.; Kaufman, H.L.; Amatruda, T.; Nemunaitis, M.; Reid, T.; Daniels, G.; Gonzalez, R.; Glaspy, J.; Whitman, E.; Harrington, K.; et al. Phase II clinical trial of a granulocyte-macrophage colony-stimulating factor-encoding, second-generation oncolytic herpesvirus in patients with unresectable metastatic melanoma. J. Clin. Oncol. 2009, 27, 5763-5771. [CrossRef] [PubMed]

10. Harrington, K.J.; Hingorani, M.; Tanay, M.A.; Hickey, J.; Bhide, S.A.; Clarke, P.M.; Renouf, L.C.; Thway, K.; Sibtain, A.; McNeish, I.A.; et al. Phase I/II study of oncolytic HSV GM-CSF in combination with radiotherapy and cisplatin in untreated stage III/IV squamous cell cancer of the head and neck. Clin. Cancer Res. 2010, 16, 4005-4015. [CrossRef] [PubMed]

11. Markert, J.M.; Liechty, P.G.; Wang, W.; Gaston, S.; Braz, E.; Karrasch, M.; Nabors, L.B.; Markiewicz, M.; Lakeman, A.D.; Palmer, C.A.; et al. Phase Ib trial of mutant herpes simplex virus G207 inoculated pre- and post-tumor resection for recurrent GBM. Mol. Ther. 2009, 17, 199-207. [CrossRef] [PubMed]

12. Markert, J.M.; Medlock, M.D.; Rabkin, S.D.; Gillespie, G.Y.; Todo, T.; Hunter, W.D.; Palmer, C.A.; Feigenbaum, F.; Tornatore, C.; Tufaro, F.; et al. Conditionally replicating herpes simplex virus mutant, g207 for the treatment of malignant glioma: Results of a phase I trial. Gene Ther. 2000, 7, 867-874. [CrossRef] [PubMed]

13. Mace, A.T.; Ganly, I.; Soutar, D.S.; Brown, S.M. Potential for efficacy of the oncolytic herpes simplex virus 1716 in patients with oral squamous cell carcinoma. Head Neck 2008, 30, 1045-1051. [CrossRef] [PubMed] 
14. MacKie, R.M.; Stewart, B.; Brown, S.M. Intralesional injection of herpes simplex virus 1716 in metastatic melanoma. Lancet 2001, 357, 525-526. [CrossRef]

15. Fong, Y.; Kim, T.; Bhargava, A.; Schwartz, L.; Brown, K.; Brody, L.; Covey, A.; Karrasch, M.; Getrajdman, G.; Mescheder, A.; et al. A herpes oncolytic virus can be delivered via the vasculature to produce biologic changes in human colorectal cancer. Mol. Ther. 2009, 17, 389-394. [CrossRef] [PubMed]

16. Nakao, A.; Kasuya, H.; Sahin, T.T.; Nomura, N.; Kanzaki, A.; Misawa, M.; Shirota, T.; Yamada, S.; Fujii, T.; Sugimoto, H.; et al. A phase I dose-escalation clinical trial of intraoperative direct intratumoral injection of HF10 oncolytic virus in non-resectable patients with advanced pancreatic cancer. Cancer Gene Ther. 2011, 18, 167-175. [CrossRef] [PubMed]

17. Kimata, H.; Imai, T.; Kikumori, T.; Teshigahara, O.; Nagasaka, T.; Goshima, F.; Nishiyama, Y.; Nakao, A. Pilot study of oncolytic viral therapy using mutant herpes simplex virus (HF10) against recurrent metastatic breast cancer. Ann. Surg. Oncol. 2006, 13, 1078-1084. [CrossRef] [PubMed]

18. Fujimoto, Y.; Mizuno, T.; Sugiura, S.; Goshima, F.; Kohno, S.; Nakashima, T.; Nishiyama, Y. Intratumoral injection of herpes simplex virus HF10 in recurrent head and neck squamous cell carcinoma. Acta Oto-Laryngol. 2006, 126, 1115-1117. [CrossRef] [PubMed]

19. Miest, T.S.; Cattaneo, R. New viruses for cancer therapy: Meeting clinical needs. Nat. Rev. Microbiol. 2014, 12, 23-34. [CrossRef] [PubMed]

20. Russell, S.J.; Peng, K.W.; Bell, J.C. Oncolytic virotherapy. Nat. Biotechnol. 2012, 30, 658-670. [CrossRef] [PubMed]

21. Cripe, T.P.; Chen, C.Y.; Denton, N.L.; Haworth, K.B.; Hutzen, B.; Leddon, J.L.; Streby, K.A.; Wang, P.Y.; Markert, J.M.; Waters, A.M.; et al. Pediatric cancer gone viral. Part I: Strategies for utilizing oncolytic herpes simplex virus-1 in children. Mol. Ther. Oncolytics 2015, 2. [CrossRef] [PubMed]

22. Toda, M.; Martuza, R.L.; Kojima, H.; Rabkin, S.D. In situ cancer vaccination: An IL-12 defective vector/replication-competent herpes simplex virus combination induces local and systemic antitumor activity. J. Immunol. 1998, 160, 4457-4464. [PubMed]

23. Andreansky, S.; He, B.; van Cott, J.; McGhee, J.; Markert, J.M.; Gillespie, G.Y.; Roizman, B.; Whitley, R.J. Treatment of intracranial gliomas in immunocompetent mice using herpes simplex viruses that express murine interleukins. Gene Ther. 1998, 5, 121-130. [CrossRef] [PubMed]

24. Parker, J.N.; Gillespie, G.Y.; Love, C.E.; Randall, S.; Whitley, R.J.; Markert, J.M. Engineered herpes simplex virus expressing IL-12 in the treatment of experimental murine brain tumors. Proc. Natl. Acad. Sci. USA 2000, 97, 2208-2213. [CrossRef] [PubMed]

25. Liu, B.L.; Robinson, M.; Han, Z.Q.; Branston, R.H.; English, C.; Reay, P.; McGrath, Y.; Thomas, S.K.; Thornton, M.; Bullock, P.; et al. ICP34.5 deleted herpes simplex virus with enhanced oncolytic, immune stimulating, and anti-tumour properties. Gene Ther. 2003, 10, 292-303. [CrossRef] [PubMed]

26. Andtbacka, R.H.; Kaufman, H.L.; Collichio, F.; Amatruda, T.; Senzer, N.; Chesney, J.; Delman, K.A.; Spitler, L.E.; Puzanov, I.; Agarwala, S.S.; et al. Talimogene laherparepvec improves durable response rate in patients with advanced melanoma. J. Clin. Oncol. 2015. [CrossRef] [PubMed]

27. Fda.gov/newsevents/newsroom/pressannouncements. Available online: http://www.webcitation.org/ 6drvCltG7 (accessed on 18 December 2015).

28. Laquerre, S.; Anderson, D.B.; Stolz, D.B.; Glorioso, J.C. Recombinant herpes simplex virus type 1 engineered for targeted binding to erythropoietin receptor-bearing cells. J. Virol. 1998, 72, 9683-9697. [PubMed]

29. Campadelli-Fiume, G.; Menotti, L.; Avitabile, E.; Gianni, T. Viral and cellular contributions to herpes simplex virus entry into the cell. Curr. Opin. Virol. 2012, 2, 28-36. [CrossRef] [PubMed]

30. Connolly, S.A.; Jackson, J.O.; Jardetzky, T.S.; Longnecker, R. Fusing structure and function: A structural view of the herpesvirus entry machinery. Nat. Rev. Microbiol. 2011, 9, 369-381. [CrossRef] [PubMed]

31. Campadelli-Fiume, G.; Amasio, M.; Avitabile, E.; Cerretani, A.; Forghieri, C.; Gianni, T.; Menotti, L. The multipartite system that mediates entry of herpes simplex virus into the cell. Rev. Med. Virol. 2007, 17, 313-326. [CrossRef] [PubMed]

32. Backovic, M.; DuBois, R.M.; Cockburn, J.J.; Sharff, A.J.; Vaney, M.C.; Granzow, H.; Klupp, B.G.; Bricogne, G.; Mettenleiter, T.C.; Rey, F.A. Structure of a core fragment of glycoprotein H from pseudorabies virus in complex with antibody. Proc. Natl. Acad. Sci. USA 2010, 107, 22635-22640. [CrossRef] [PubMed] 
33. Chowdary, T.K.; Cairns, T.M.; Atanasiu, D.; Cohen, G.H.; Eisenberg, R.J.; Heldwein, E.E. Crystal structure of the conserved herpesvirus fusion regulator complex gH-gL. Nat. Struct. Mol. Biol. 2010, 17, 882-888. [CrossRef] [PubMed]

34. Rey, F.A. Molecular gymnastics at the herpesvirus surface. EMBO Rep. 2006, 7, 1000-1005. [CrossRef] [PubMed]

35. Cocchi, F.; Menotti, L.; Mirandola, P.; Lopez, M.; Campadelli-Fiume, G. The ectodomain of a novel member of the immunoglobulin subfamily related to the poliovirus receptor has the attributes of a bona fide receptor for herpes simplex virus types 1 and 2 in human cells. J. Virol. 1998, 72, 9992-10002. [PubMed]

36. Geraghty, R.J.; Krummenacher, C.; Cohen, G.H.; Eisenberg, R.J.; Spear, P.G. Entry of alphaherpesviruses mediated by poliovirus receptor-related protein 1 and poliovirus receptor. Science 1998, 280, 1618-1620. [CrossRef] [PubMed]

37. Shukla, D.; Liu, J.; Blaiklock, P.; Shworak, N.W.; Bai, X.; Esko, J.D.; Cohen, G.H.; Eisenberg, R.J.; Rosenberg, R.D.; Spear, P.G. A novel role for 3-o-sulfated heparan sulfate in herpes simplex virus 1 entry. Cell 1999, 99, 13-22. [CrossRef]

38. Montgomery, R.I.; Warner, M.S.; Lum, B.J.; Spear, P.G. Herpes simplex virus-1 entry into cells mediated by a novel member of the TNF/NGF receptor family. Cell 1996, 87, 427-436. [CrossRef]

39. Carfi, A.; Willis, S.H.; Whitbeck, J.C.; Krummenacher, C.; Cohen, G.H.; Eisenberg, R.J.; Wiley, D.C. Herpes simplex virus glycoprotein D bound to the human receptor HveA. Mol. Cell 2001, 8, 169-179. [CrossRef]

40. Krummenacher, C.; Supekar, V.M.; Whitbeck, J.C.; Lazear, E.; Connolly, S.A.; Eisenberg, R.J.; Cohen, G.H.; Wiley, D.C.; Carfi, A. Structure of unliganded HSV gD reveals a mechanism for receptor-mediated activation of virus entry. EMBO J. 2005, 24, 4144-4153. [CrossRef] [PubMed]

41. Di Giovine, P.; Settembre, E.C.; Bhargava, A.K.; Luftig, M.A.; Lou, H.; Cohen, G.H.; Eisenberg, R.J.; Krummenacher, C.; Carfi, A. Structure of herpes simplex virus glycoprotein D bound to the human receptor nectin-1. PLoS Pathog. 2011, 7. [CrossRef] [PubMed]

42. Cocchi, F.; Menotti, L.; di Ninni, V.; Lopez, M.; Campadelli-Fiume, G. The herpes simplex virus JMP mutant enters receptor-negative J cells through a novel pathway independent of the known receptors nectin1, HveA, and nectin2. J. Virol. 2004, 78, 4720-4729. [CrossRef] [PubMed]

43. Fusco, D.; Forghieri, C.; Campadelli-Fiume, G. The pro-fusion domain of herpes simplex virus glycoprotein $\mathrm{D}(\mathrm{gD})$ interacts with the $\mathrm{gD} \mathrm{N}$ terminus and is displaced by soluble forms of viral receptors. Proc. Natl. Acad. Sci. USA 2005, 102, 9323-9328. [CrossRef] [PubMed]

44. Gianni, T.; Massaro, R.; Campadelli-Fiume, G. Dissociation of HSV gL from gH by $\alpha \mathrm{v} \beta 6$ - or $\alpha \mathrm{v} \beta 8$-integrin promotes gH activation and virus entry. Proc. Natl. Acad. Sci. USA 2015, 112, E3901-E3910. [CrossRef] [PubMed]

45. Atanasiu, D.; Cairns, T.M.; Whitbeck, J.C.; Saw, W.T.; Rao, S.; Eisenberg, R.J.; Cohen, G.H. Regulation of herpes simplex virus gB-induced cell-cell fusion by mutant forms of $\mathrm{gH} / \mathrm{gL}$ in the absence of $\mathrm{gD}$ and cellular receptors. MBio 2013, 4. [CrossRef] [PubMed]

46. Galdiero, S.; Falanga, A.; Vitiello, M.; Raiola, L.; Fattorusso, R.; Browne, H.; Pedone, C.; Isernia, C.; Galdiero, M. Analysis of a membrane interacting region of herpes simplex virus type 1 glycoprotein $\mathrm{H}$. J. Biol. Chem. 2008, 283, 29993-30009. [CrossRef] [PubMed]

47. Zhou, G.; Roizman, B. Construction and properties of a herpes simplex virus 1 designed to enter cells solely via the IL-13 $\alpha 2$ receptor. Proc. Natl. Acad. Sci. USA 2006, 103, 5508-5513. [CrossRef] [PubMed]

48. Zhou, G.; Ye, G.J.; Debinski, W.; Roizman, B. Engineered herpes simplex virus 1 is dependent on IL13R $\alpha 2$ receptor for cell entry and independent of glycoprotein D receptor interaction. Proc. Natl. Acad. Sci. USA 2002, 99, 15124-15129. [CrossRef] [PubMed]

49. Zhou, G.; Roizman, B. Separation of receptor binding and pro-fusogenic domains of glycoprotein D of herpes simplex virus 1 into distinct interacting proteins. Proc. Natl. Acad. Sci. USA 2007, 104, 4142-4146. [CrossRef] [PubMed]

50. Menotti, L.; Cerretani, A.; Hengel, H.; Campadelli-Fiume, G. Construction of a fully retargeted herpes simplex virus 1 recombinant capable of entering cells solely via human epidermal growth factor receptor 2. J. Virol. 2008, 20, 10153-10161. [CrossRef] [PubMed]

51. Jackson, C.; Browell, D.; Gautrey, H.; Tyson-Capper, A. Clinical significance of HER-2 splice variants in breast cancer progression and drug resistance. Int. J. Cell Biol. 2013. [CrossRef] [PubMed] 
52. Menotti, L.; Cerretani, A.; Campadelli-Fiume, G. A herpes simplex virus recombinant that exhibits a single-chain antibody to HER2/neu enters cells through the mammary tumor receptor, independently of the gD receptors. J. Virol. 2006, 80, 5531-5539. [CrossRef] [PubMed]

53. Menotti, L.; Nicoletti, G.; Gatta, V.; Croci, S.; Landuzzi, L.; de Giovanni, C.; Nanni, P.; Lollini, P.L.; Campadelli-Fiume, G. Inhibition of human tumor growth in mice by an oncolytic herpes simplex virus designed to target solely HER-2-positive cells. Proc. Natl. Acad. Sci. USA 2009, 106, 9039-9044. [CrossRef] [PubMed]

54. Kubetzko, S.; Balic, E.; Waibel, R.; Zangemeister-Wittke, U.; Pluckthun, A. PEGylation and multimerization of the Anti-p185HER-2 single chain Fv fragment 4D5: Effects on tumor targeting. J. Biol. Chem. 2006, 281, 35186-35201. [CrossRef] [PubMed]

55. Nanni, P.; Gatta, V.; Menotti, L.; de Giovanni, C.; Ianzano, M.; Palladini, A.; Grosso, V.; Dall'ora, M.; Croci, S.; Nicoletti, G.; et al. Preclinical therapy of disseminated HER-2 ${ }^{+}$ovarian and breast carcinomas with a HER-2-retargeted oncolytic herpesvirus. PLoS Pathog. 2013, 9. [CrossRef] [PubMed]

56. Gambini, E.; Reisoli, E.; Appolloni, I.; Gatta, V.; Campadelli-Fiume, G.; Menotti, L.; Malatesta, P. Replication-competent herpes simplex virus retargeted to HER2 as therapy for high-grade glioma. Mol. Ther. 2012, 20, 994-1001. [CrossRef] [PubMed]

57. Leoni, V.; Gatta, V.; Palladini, A.; Nicoletti, G.; Ranieri, D.; Dall’Ora, M.; Grosso, V.; Rossi, M.; Alviano, F.; Bonsi, L.; et al. Systemic delivery of HER2-retargeted oncolytic-HSV by mesenchymal stromal cells protects from lung and brain metastases. Oncotarget 2015, 6, 34774-34787. [PubMed]

58. Uchida, H.; Marzulli, M.; Nakano, K.; Goins, W.F.; Chan, J.; Hong, C.S.; Mazzacurati, L.; Yoo, J.Y.; Haseley, A.; Nakashima, H.; et al. Effective treatment of an orthotopic xenograft model of human glioblastoma using an EGFR-retargeted oncolytic herpes simplex virus. Mol. Ther. 2013, 21, 561-569. [CrossRef] [PubMed]

59. Cattaneo, R.; Miest, T.; Shashkova, E.V.; Barry, M.A. Reprogrammed viruses as cancer therapeutics: Targeted, armed and shielded. Nat. Rev. Microbiol. 2008, 6, 529-540. [CrossRef] [PubMed]

60. Nakamura, T.; Peng, K.W.; Harvey, M.; Greiner, S.; Lorimer, I.A.; James, C.D.; Russell, S.J. Rescue and propagation of fully retargeted oncolytic measles viruses. Nat. Biotechnol. 2005, 23, 209-214. [CrossRef] [PubMed]

61. Friedrich, K.; Hanauer, J.R.; Prufer, S.; Munch, R.C.; Volker, I.; Filippis, C.; Jost, C.; Hanschmann, K.M.; Cattaneo, R.; Peng, K.W.; et al. Darpin-targeting of measles virus: Unique bispecificity, effective oncolysis, and enhanced safety. Mol. Ther. 2013, 21, 849-859. [CrossRef] [PubMed]

62. Klupp, B.G.; Mettenleiter, T.C. Glycoprotein gL-independent infectivity of pseudorabies virus is mediated by a gD-gH fusion protein. J. Virol. 1999, 73, 3014-3022. [PubMed]

63. Cairns, T.M.; Milne, R.S.; Ponce-de-Leon, M.; Tobin, D.K.; Cohen, G.H.; Eisenberg, R.J. Structure-function analysis of herpes simplex virus type $1 \mathrm{gD}$ and $\mathrm{gH}-\mathrm{gL}$ : Clues from $\mathrm{gDgH}$ chimeras. J. Virol. 2003, 77, 6731-6742. [CrossRef] [PubMed]

64. Gatta, V.; Petrovic, B.; Campadelli-Fiume, G. The engineering of a novel ligand in gH confers to HSV an expanded tropism independent of gD activation by its receptors. PLoS Pathog. 2015, 11. [CrossRef] [PubMed]

65. Kanai, R.; Tomita, H.; Shinoda, A.; Takahashi, M.; Goldman, S.; Okano, H.; Kawase, T.; Yazaki, T. Enhanced therapeutic efficacy of G207 for the treatment of glioma through Musashi1 promoter retargeting of $\gamma 34.5$-mediated virulence. Gene Ther. 2006, 13, 106-116. [CrossRef] [PubMed]

66. Lee, C.Y.; Bu, L.X.; DeBenedetti, A.; Williams, B.J.; Rennie, P.S.; Jia, W.W. Transcriptional and translational dual-regulated oncolytic herpes simplex virus type 1 for targeting prostate tumors. Mol. Ther. 2010, 18, 929-935. [CrossRef] [PubMed]

67. Foka, P.; Pourchet, A.; Hernandez-Alcoceba, R.; Doumba, P.P.; Pissas, G.; Kouvatsis, V.; Dalagiorgou, G.; Kazazi, D.; Marconi, P.; Foschini, M.; et al. Novel tumour-specific promoters for transcriptional targeting of hepatocellular carcinoma by herpes simplex virus vectors. J. Gene Med. 2010, 12, 956-967. [CrossRef] [PubMed]

68. Longo, S.L.; Griffith, C.; Glass, A.; Shillitoe, E.J.; Post, D.E. Development of an oncolytic herpes simplex virus using a tumor-specific HIF-responsive promoter. Cancer Gene Ther. 2011, 18, 123-134. [CrossRef] [PubMed]

69. Mazzacurati, L.; Marzulli, M.; Reinhart, B.; Miyagawa, Y.; Uchida, H.; Goins, W.F.; Li, A.; Kaur, B.; Caligiuri, M.; Cripe, T.; et al. Use of miRNA response sequences to block off-target replication and increase the safety of an unattenuated, glioblastoma-targeted oncolytic HSV. Mol. Ther. 2015, 23, 99-107. [CrossRef] [PubMed] 
70. Coffin, R.S. From virotherapy to oncolytic immunotherapy: Where are we now? Curr. Opin. Virol. 2015, 13, 93-100. [CrossRef] [PubMed]

71. Varghese, S.; Rabkin, S.D.; Nielsen, G.P.; MacGarvey, U.; Liu, R.; Martuza, R.L. Systemic therapy of spontaneous prostate cancer in transgenic mice with oncolytic herpes simplex viruses. Cancer Res. 2007, 67, 9371-9379. [CrossRef] [PubMed]

72. Fu, X.; Zhang, X. Potent systemic antitumor activity from an oncolytic herpes simplex virus of syncytial phenotype. Cancer Res. 2002, 62, 2306-2312. [PubMed]

73. Kulu, Y.; Dorfman, J.D.; Kuruppu, D.; Fuchs, B.C.; Goodwin, J.M.; Fujii, T.; Kuroda, T.; Lanuti, M.; Tanabe, K.K. Comparison of intravenous vs. intraperitoneal administration of oncolytic herpes simplex virus 1 for peritoneal carcinomatosis in mice. Cancer Gene Ther. 2009, 16, 291-297. [CrossRef] [PubMed]

74. Wang, J.; Hu, P.; Zeng, M.; Rabkin, S.D.; Liu, R. Oncolytic herpes simplex virus treatment of metastatic breast cancer. Int. J. Oncol. 2012, 40, 757-763. [PubMed]

75. Kemeny, N.; Brown, K.; Covey, A.; Kim, T.; Bhargava, A.; Brody, L.; Guilfoyle, B.; Haag, N.P.; Karrasch, M.; Glasschroeder, B.; et al. Phase I, open-label, dose-escalating study of a genetically engineered herpes simplex virus, NV1020, in subjects with metastatic colorectal carcinoma to the liver. Hum. Gene Ther. 2006, 17, 1214-1224. [CrossRef] [PubMed]

76. Geevarghese, S.K.; Chen, A.; Geller, D.A.; de Haan, H.A.; Iagaru, A.; Knoll, A.; Nemunaitis, J.; Reid, T.R.; Sze, D.Y.; Tanabe, K. Phase II efficacy results using an oncolytic herpes simplex virus (NV1020) in patients with colorectal cancer metastatic to liver (mCRC). J. Clin. Oncol. 2009, 27, 4089.

77. Russell, S.J.; Peng, K.W. The utility of cells as vehicles for oncolytic virus therapies. Curr. Opin. Mol. Ther. 2008, 10, 380-386. [PubMed]

78. Munguia, A.; Ota, T.; Miest, T.; Russell, S.J. Cell carriers to deliver oncolytic viruses to sites of myeloma tumor growth. Gene Ther. 2008, 15, 797-806. [CrossRef] [PubMed]

79. Willmon, C.; Harrington, K.; Kottke, T.; Prestwich, R.; Melcher, A.; Vile, R. Cell carriers for oncolytic viruses: Fed Ex for cancer therapy. Mol. Ther. 2009, 17, 1667-1676. [CrossRef] [PubMed]

80. Coukos, G.; Makrigiannakis, A.; Kang, E.H.; Caparelli, D.; Benjamin, I.; Kaiser, L.R.; Rubin, S.C.; Albelda, S.M.; Molnar-Kimber, K.L. Use of carrier cells to deliver a replication-selective herpes simplex virus-1 mutant for the intraperitoneal therapy of epithelial ovarian cancer. Clin. Cancer Res. 1999, 5, 1523-1537. [PubMed]

81. Hammer, K.; Kazcorowski, A.; Liu, L.; Behr, M.; Schemmer, P.; Herr, I.; Nettelbeck, D.M. Engineered adenoviruses combine enhanced oncolysis with improved virus production by mesenchymal stromal carrier cells. Int. J. Cancer 2015, 13, 978-990. [CrossRef]

82. Ilett, E.; Kottke, T.; Donnelly, O.; Thompson, J.; Willmon, C.; Diaz, R.; Zaidi, S.; Coffey, M.; Selby, P.; Harrington, K.; et al. Cytokine conditioning enhances systemic delivery and therapy of an oncolytic virus. Mol. Ther. 2014, 22, 1851-1863. [CrossRef]

83. Hsiao, W.C.; Sung, S.Y.; Liao, C.H.; Wu, H.C.; Hsieh, C.L. Vitamin D3-inducible mesenchymal stem cell-based delivery of conditionally replicating adenoviruses effectively targets renal cell carcinoma and inhibits tumor growth. Mol. Pharm. 2012, 9, 1396-1408. [CrossRef] [PubMed]

84. Castleton, A.; Dey, A.; Beaton, B.; Patel, B.; Aucher, A.; Davis, D.M.; Fielding, A.K. Human mesenchymal stromal cells deliver systemic oncolytic measles virus to treat acute lymphoblastic leukemia in the presence of humoral immunity. Blood 2014, 123, 1327-1335. [CrossRef] [PubMed]

85. Duebgen, M.; Martinez-Quintanilla, J.; Tamura, K.; Hingtgen, S.; Redjal, N.; Wakimoto, H.; Shah, K. Stem cells loaded with multimechanistic oncolytic herpes simplex virus variants for brain tumor therapy. J. Natl. Cancer Inst. 2014, 106. [CrossRef] [PubMed]

86. Fujiwara, S.; Nawa, A.; Luo, C.; Kamakura, M.; Goshima, F.; Kondo, C.; Kiyono, T.; Kikkawa, F.; Nishiyama, Y. Carrier cell-based delivery of replication-competent HSV-1 mutants enhances antitumor effect for ovarian cancer. Cancer Gene Ther. 2011, 18, 77-86. [CrossRef] [PubMed]

87. Nakashima, H.; Kaur, B.; Chiocca, E.A. Directing systemic oncolytic viral delivery to tumors via carrier cells. Cytokine Growth Factor Rev. 2010, 21, 119-126. [CrossRef] [PubMed]

(C) 2016 by the authors; licensee MDPI, Basel, Switzerland. This article is an open access article distributed under the terms and conditions of the Creative Commons by Attribution (CC-BY) license (http://creativecommons.org/licenses/by/4.0/). 